\title{
Communication
}

[Comunicação]

\section{Occurrence of Struthiopterolichus bicaudatus (Acari; Pterolichidae) in Southeastern Brazil}

[Ocorrência de Struthiopterolichus bicaudatus (Acari; Pterolichidae) no sudeste brasileiro]

\author{
J.L.H. Faccini ${ }^{1,5}$, G.G. Verocai ${ }^{2,5}$, L.N. Lopes $^{3}$, C.P. Souza $a^{4,5}$ \\ ${ }^{1}$ Departamento de Parasitologia Animal - UFRRJ \\ BR $465, \mathrm{~km} 7$ \\ 23.890-000 - Seropédica, RJ \\ ${ }^{2}$ Aluno de graduação - UFRRJ \\ ${ }^{3}$ Médico Veterinário autônomo. \\ ${ }^{4}$ Aluna de pós-graduação - UFRRJ \\ ${ }^{5} \mathrm{Bolsista} \mathrm{CNPq}$
}

Ostrich (Struthio camelus) farming is a worldwide commercial activity for the production of feathers, leather and meat. In Brazil, the ostrich farming started in the mid nineties. The first farmed ostriches were probably imported from their original distribution areas (mainly South Africa).

As reported for other importing countries (Gordo et al., 2002), some ostrich parasites have been brought to Brazil with the birds as well.

The aim of the present work was to report the occurrence of the feather mite Struthiopterolichus bicaudatus (Gervais) in an ostrich farm from Southeastern Brazil.

The farm is located in the county of Caratinga, State of Minas Gerais, Southeastern Brazil The diagnosis of parasitism was done during husbandry practices that include monthly handle of the birds for weighting and general physical examination. In September, 2004, all birds of the farm were examined and classified according to their age: 0 to 3 month-old ( 15 birds), 4 to 12 month-old (45 birds), 13 a 24 month-old (224 birds), older than 24 months (61 birds), totaling 345 birds.

Three wing feathers were collected and taken to the laboratory, to be examined for ectoparasites under a stereomicroscope at 10-60× magnification.

The ectoparasites found were stored in $70 \%$ commercial ethanol until slide mounts in Hoyer's were made. Mites were tentatively identified as $S$. bicaudatus. Although the feather mites associated with ostriches are known long ago, the taxonomic position of at least five described species (André, 1960) is still controversial. Recent researches mentioned Gabucinia bicaudata (Gabuciniidae) (McKenna, 2001; Gordo et al., 2002; Ribeiro et al., 2004) or Pterolichus bicaudatus (Pterolichidae) (Cooper, 2005). However, Gaud and Atyeo (1996), leading scientists maintained this species in the genus Struthiopterolichus (Pterolichidae).

The main signs of infestations such as broken feathers with damaged or lacking barbs, primarily in the large wing feathers, and pruritus were only seen in all 285 birds older than 13 months. McKenna (2001) reported a similar situation in a flock of ostrich from New Zealand - all 150 adult birds were apparently parasitized by a species of Gabucinia. Damaged feathers were seen in birds with different parasitic loads. Gordo et al. (2002) have observed intense pruritus and feather loss in some, but not in all ostriches with high intensity of ectoparasite infestation.

Recebido em 24 de abril de 2005

Aceito em 7 de agosto de 2006

E-mail: faccini@ufrrj.br

Apoio: CNPq / CAPES 
Although the feather mites are known as non detrimental to the health of their hosts even in high infestations, heavy infestations of Megninia (Analgidae) can cause financial losses in modern poultry industry and large populations of Dubininia melopsittaci (Xolalgidae) may harm the typical host, the budgerigar (Gaud and Atyeo, 1996).

Most birds of the farm belong to the breed African black but crossbred individuals with predominance of the African black phenotype were present as well.

The origin of the infestation is uncertain since birds were acquired from other known national commercial farms located in the States of Alagoas, Bahia (Northeast) and Minas Gerais (Southeast). This species has also been reported from an ostrich farm in the State of Rio Grande do Sul as Gabucinia bicaudata by Ribeiro et al. (2004) and collected from an ostrich farm in the State of Rio de Janeiro by Coumendouros ${ }^{1}$. In both localities, damaged feathers associated with mites were seen. The occurrence of $S$. bicaudatus in Southeastern and Southern states suggests a wide-range distribution in Brazil.

The economic impact of these mites on ostrich farms is still undetermined. Another important aspect to consider is that the host relationship of these ectoparasites is also unknown. Are they ratite-specific or also shared with other host birds as poultry or wildlife? It should be remembered that in nowadays the translocations of hosts or parasites from one ecosystem to another is an important factor leading to the emergence of diseases (Daszak et al., 2000). Further studies are urgently needed to determine the exact taxonomic status, host specificity and the economic impact of the feather mites associated with the ratites.

Keywords: ostrich, Struthiopterolichus bicaudatus, Acari, Pterolichidae

\section{RESUMO}

A ocorrência de Struthiopterolichus bicaudatus é assinalada em uma criação de avestruz no estado de Minas Gerais. Os principais sinais associados com a presença dos ácaros foram penas quebradas com a falta de barbas no vexilo, principalmente nas penas das asas, e prurido. Esses sinais foram observados em todas as aves do plantel (285 animais) com idade acima de 13 meses. As aves com idade abaixo de 13 meses (60 animais) não apresentaram qualquer sinal, tampouco ácaros.

Palavras-chave: avestruz, Struthiopterolichus bicaudatus, Acari, Pterolichidae

\section{REFERENCES}

ANDRÉ, M. Sarcoptides plumicoles parasites des austriches. Acarologia, v.2, p. 556-567,1960.

COOPER, R.G. Bacterial, fungal and parasitic infections in the ostrich (Struthio camelus var. domesticus). Anim. Sci. J., p. 97-106, 2005.

DASZAK P.; CUNNINGHARN, A.A.; HYATT A.D. Emerging infectious diseases of wildlife threats to biodiversity and human health. Science, v. 287, p. 443-449, 2000.

GAUD, J.; ATYEO, W.T. Feather mites of the world (Acarina, Astigmata): the supraspecific taxa. Part I. Ann. Sci. Zool., v.277, p. 1-193, 1996.
GORDO F.P.; HERRERA S.; CASTRO A.T. et al. Parasites from farmed ostriches (Struthio camelus) and rheas (Rhea americana) in Europe. Vet. Parasitol., v.107, p.137-160, 2002.

McKENNA, P.B. Register of new host - parasite records. Surveillance, v.28, p.4-5, 2001.

RIBEIRO, V.L.S.; RIBEIRO, M.M. PERUZZI, J. et al. Ocorrência de Gabucinia bicaudata (Acari: Gabuciniidae) em Struthio camelus (Struthioniformes: Struthionidae) no Rio Grande do Sul, Brasil. Rev. Bras. Parasitol. Vet., v.13, supl. 1, p. 346, 2004.

${ }^{1}$ Coumendouros, K. (personal communication) - UFRRJ, 2005 